\title{
Adsorption of arsenic and phosphate from groundwater onto a calcined laterite as fixed bed in column experiments
}

\author{
Yacouba Sanou*, Raymond Kabore, Samuel Pare \\ Laboratory of Analytical, Environmental and Bio-Organic Chemistry, chemistry department, \\ University Joseph KI-ZERBO, 03 BP 7021, Burkina Faso. \\ prosperyacson@gmail.com
}

Keywords: Adsorption, arsenic, laterite soil, groundwater, phosphate.

This work was focused on laterite soil as adsorbent for the removal of arsenic and phosphate from groundwater using column experiments. Results revealed a decrease of arsenic removal efficiency from 100 to $79 \%$ with flow rate increasing. Maximum removal of $100 \%$ for arsenic and $85 \%$ for phosphates was obtained for $\mathrm{pH}$ values between 3.5 and 6 . The increase of initial arsenic concentration and phosphate amount caused an increase of arsenic adsorption up to $24 \mu \mathrm{g} / \mathrm{g}$ while $58.5 \mu \mathrm{g} / \mathrm{g}$ for phosphate. $\mathrm{NaOH}$ solution could desorb $86.8 \%$ of arsenic and the reuse of regenerated laterite indicated its efficiency in same experimental conditions.

\section{Introduction}

Nowadays, water sector is facing many challenges such as qualitative and quantitative degradations, increasing demand, scarcity, pollution and climatic conditions [1]. Arsenic is a toxic and carcinogenic metalloid whose the accumulation in human body causes public health problems [2]. In recent decades, great interest has been focused to the research on the presence and behavior of arsenic in environment because of serious problems caused by this element, its removal from aqueous media is strongly influenced by the presence of phosphates [3, 4]. In Burkina Faso, previous study revealed that $15.5 \%$ of drilling water in Ganzourgou Province, $42 \%$ of groundwater in Yatenga Province, $13 \%$ of drilling water in Soum
Province, $16 \%$ of groundwater in Balé Province and $14 \%$ of drilling water in Bam Province did contain an arsenic concentration above the permissible limit value, $10 \mu \mathrm{g} / \mathrm{L}$ [5]. The high concentration of phosphates in soils and water promotes the rapid development of algae causing the eutrophication of lakes and rivers $[6,7]$. The high concentration of inorganic phosphates greater than $0.2 \mathrm{mg} / \mathrm{L}$ causes a high accumulation of sediment and organic matter, a reduction in dissolved oxygen in water and the death of organisms, such as phytoplankton by cyanobacteria adapted to new conditions, color appearance and odor release [8]. Groundwater has a phosphate content ranging from 0.8 to 1.2 $\mathrm{mg} / \mathrm{L}$ which is part of the rapid deterioration in the quality of groundwater storage in jars and 
interferes with the removal of arsenic. Phosphate is essential for plant growth in soils and it has been recognized as one of main nutrients controlling eutrophication in surface water bodies $[9,10]$. It has been demonstrated that the mobilization of phosphate in the environment is strongly influenced by mineral surfaces on which adsorption determines the quantity of phosphate retained in the solid phase of soils and waters; that is one of the main processes which affect and control the transport and bioavailability of this anion [11]. The low mobility of phosphate is due to its high reactivity with many soil components such as clays, laterites, metal oxides and hydroxides and soluble metal cations [12]. The presence of phosphates in high concentrations in water negatively influences the removal of arsenic [13, 14]. The research of low-cost adsorbents that are less harmful to the environment has led to favoring the choice of natural materials such as laterites as adsorbent for the removal of pollutants from waters [15-17]. Previous work has been carried out on the chemical composition and physicochemical properties of Balkuy laterite, but its adsorption capacity for arsenic and phosphate from water has not been studied [18-20]. The present work aims to study the adsorption capacity of laterite for the removal of arsenic and phosphates from water through the effect of flow rate, $\mathrm{pH}$, adsorbent weight and initial adsorbate concentration) as well as desorption capacity and re-adsorption of laterite.

\section{Materials and methods}

\section{Collection and characterization of laterite}

Laterite is a red or brown rock, which is formed by weathering rocks or materials rich in iron or aluminum hydroxides. The alteration of the parent rock takes place by dissolving and leaving the silica by leaching, accompanied by an enrichment in iron and alumina in the form of iron oxides $\mathrm{Fe}_{2} \mathrm{O}_{3}$ and aluminum oxides $\mathrm{Al}_{2} \mathrm{O}_{3}$. Laterite was collected at Balkuy district (12 $17^{\prime} 23.35^{\prime}$ ' N , 1²7'46.90'’ W). The sampled laterite was red okra color and hard (Fig.1). It was physically activated according to a method previously described in literature [19, 21]. Calcination leads to the transformation of hydroxyls into oxides and an increase in density, which constitutes a considerable advantage in column processing. Literature review revealed a significant presence of iron, aluminum and silica oxides in this laterite [18-19]. Some characteristics of laterite are presented in Table 1. Laterite particles with grains size between 0.4 and $0.9 \mathrm{~mm}$ were used in experiments. 


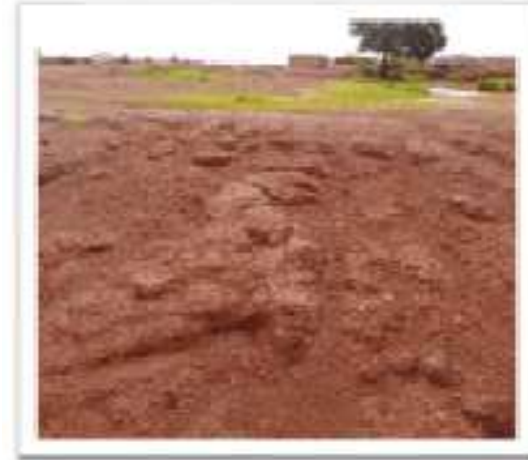

a) Raw laterite

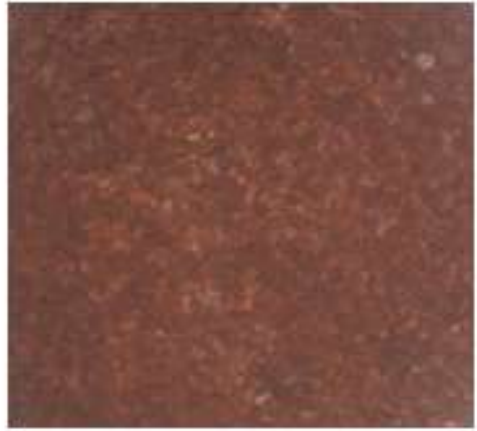

b) Calcined laterite

Figure 1. Images of raw and calcined laterites.

Table 1. Some characteristics of laterite [19]

\begin{tabular}{|c|c|}
\hline Parameter & Quantitative value \\
\hline $\mathrm{pH} \mathrm{PZC}_{\mathrm{C}}$ & 5.74 \\
\hline density $(\mathrm{g} / \mathrm{mL})$ & 2.45 \\
\hline Surface area $\left(\mathrm{m}^{2} / \mathrm{g}\right)$ & 52.47 \\
\hline Chemical & $\mathrm{Si}(21.28 \%), \mathrm{Al}(20.89 \%)$, \\
composition & $\mathrm{Fe}(8.71 \%), \mathrm{O}(45.94 \%)$ \\
& and $\mathrm{C}(1.9 \%)$ \\
\hline Oxides & $\mathrm{SiO}_{2}(44.69 \%), \mathrm{Al}_{2} \mathrm{O}_{3}$ \\
& $(40.20 \%), \mathrm{Fe}_{2} \mathrm{O}_{3}(11.21 \%)$ \\
& and others $(3.1 \%)$ \\
\hline
\end{tabular}

\section{Presentation of sampling site}

Sampling was carried out at Mogtédo city $\left(12^{\circ} 17^{\prime} 04.22^{\prime \prime} \mathrm{N}, 00^{\circ} 49^{\prime} 45.66^{\prime}\right.$ 'W) located to $82 \mathrm{~km}$ from Ouagadougou. Water used in this work was collected from a large borehole supplying fourteen (14) standpipes in the city. Indeed, Mogtédo is a mining area, gold in particular and previous studies reported some cases of arsenic pollution and high concentrations in boreholes $[19,22]$.

\section{Sampling and characterization of water sample}

Water samples were collected on November 23, 2018 in Mogtédo. Indeed, five water boxes (20 liter of volume) previously disinfected with $0.1 \mathrm{M} \mathrm{HNO}_{3}$ solution and cleaned with distilled water were used for sampling. Before each sampling, water boxes were rinsed 3 times with water to be sampled. Parameters measured in situ include $\mathrm{pH}$ and temperature using a $\mathrm{pH}$ meter (Martini, Mi 606 electrode), electrical conductivity (EC) with a conductimeter (Orion 3STAR, thermo scientific) and turbidity with a Wagtech turbidimeter. Water samples were sent to the laboratory in Ouagadougou where anions such as chlorides, phosphates, nitrates, sulfates, fluorides, bicarbonates, dissolved solids (DS), total hardness (TH), Total Alkalinity (TA), total suspended solids (TSS), and total arsenic (Total As) amount were analyzed according to APHA standard methods [23]. The hardness of water was evaluated by complexiometry with ethylene diaminetetraacetic acid. The alkalinity as determined by volumetric method with $0.02 \mathrm{~N}$ sulfuric acid while total suspended solids were determined by filtration on wattman filter paper. Sulfates, nitrates, phosphates, fluorides and chlorides were analyzed by colorimetry using an Ultraviolet spectrophotometer (Hach Lange, DR 3900). The residual arsenic concentration was analyzed by Atomic Emission Spectroscopy 
(ICP-AES). The phosphate concentration was determined by colorimetry using a UV spectrometer (HACH, DR3900) calibrated at 880 $\mathrm{nm}$. The principle consists in reacting the phosphate anions with ammonium molybdate in an acid medium to phosphomolybdic acid form which is reduced by ascorbic acid to blue molybdenum.

Pilot experimental setup

The technique of pollutant removal (As and $\mathrm{PO}_{4}{ }^{3-}$ ) was carried out with a column (length 100 $\mathrm{cm}$, internal diameter $2 \mathrm{~cm}$ ) and the experimental device was described as follows (Figure 2). Laterite grains of size between $0.4 \mathrm{~mm}$ and 0.9 $\mathrm{mm}$ were used. To immobilize the adsorbent in the column and increase the contact time, calcined laterite was framed in its lower and upper parts by a thickness of $2.5 \mathrm{~cm}$ of glass wool. Water was pumped in up flow from the influent water box to the column using an electric pump which allows to regulate the flow rate.

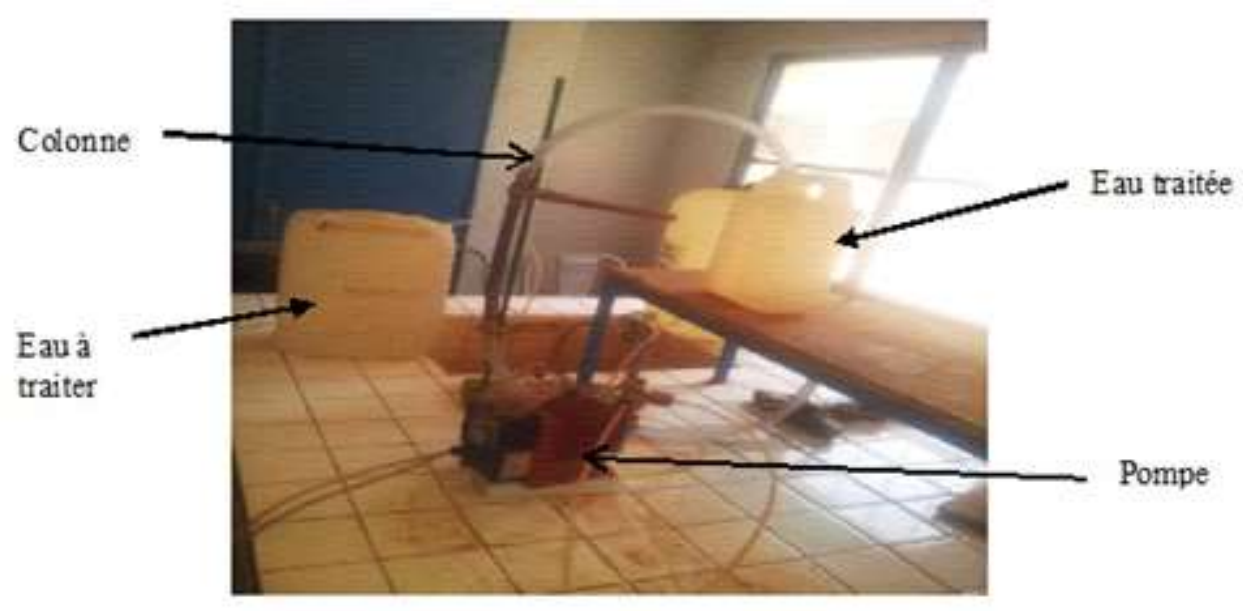

Figure 2. Experimental device of column experiments

Study of the influence of operating parameters

The influence of flow rate on the arsenic treatment efficiency was evaluated by varying the flow rate between 6.5 and $37.5 \mathrm{~mL} / \mathrm{min}$ using water with an arsenic concentration of $151 \mu \mathrm{g} / \mathrm{L}$ and a volume of $100 \mathrm{~L}$ of treated water at each value of flow rate. To assess the $\mathrm{pH}$ effect on treatment efficiency, water samples with $\mathrm{pH}$ ranged between 3.5 and 11.02, adjusted using 1 $\mathrm{M} \mathrm{NaOH}$ and $0.1 \mathrm{M} \mathrm{HCl}$ solutions were treated by percolation with an optimum flow rate of 8.5 $\mathrm{mL} / \mathrm{min}$ for better treatment of arsenic. The removal of arsenic and phosphates was studied by varying the initial arsenic content between 74 and $550 \mu \mathrm{g} / \mathrm{L}$ with a flow rate of $8.5 \mathrm{~mL} / \mathrm{min}$ and an initial phosphate concentration fixed at 1.25 $\mathrm{mg} / \mathrm{L}$. To study the influence of phosphate on arsenic removal, the initial concentration of phosphate was varied between 0.6 to $3 \mathrm{mg} / \mathrm{L}$ and that of arsenic fixed at $156 \mu \mathrm{g} / \mathrm{L}$ in water with $\mathrm{pH}$ of 7.23 and flow rate of $8.5 \mathrm{~mL} / \mathrm{min}$. To assess the effect of the laterite mass, breakthrough curves were drawn at different heights of the bed such 10,20 and $30 \mathrm{~cm}$ corresponding to $40 \mathrm{~g}, 80$ $\mathrm{g}$ and $120 \mathrm{~g}$ of laterite with a flow rate of 8.5 $\mathrm{mL} / \mathrm{min}$. 
Study of arsenic desorption and re-adsorption

Desorption of arsenic can be achieved by chemical treatment using an alkaline solution. Arsenic desorption was studied using $\mathrm{NaOH}$ and $\mathrm{KOH}$ solutions in previous work, which concluded a higher desorption of arsenic using $\mathrm{KOH}$ solution [24]. In this study, the desorption was carried out on $40 \mathrm{~g}$ of calcined laterite containing $1.692 \mathrm{mg}$ of fixed arsenic using $1 \mathrm{M}$ $\mathrm{NaOH}$ solution through the column with a flow rate of $8.5 \mathrm{~mL} / \mathrm{min}$. The use of regenerated laterite was studied by evaluating the readsorption capacity of regenerated laterite and comparing to the one of calcined laterite using 10 $\mathrm{g}$ of each laterite and a flow rate of $8.5 \mathrm{~mL} / \mathrm{min}$.

\section{Calculations}

The adsorption capacity Q ( $\mu \mathrm{g} / \mathrm{g})$ was calculated from the relation (1):

$$
\mathrm{Q}=\frac{q_{\text {tot }}}{m}
$$

With $\mathrm{m}$ : mass of laterite $(\mathrm{g})$ and $\mathrm{q}_{\text {tot: }}$ total quantity of adsorbed pollutants in column $(\mu \mathrm{g})$.

The total amount of phosphates or arsenic introduced into the column was calculated by:

$$
m_{\text {tot }}(\mu g)=C_{0 .} d x t
$$

With $\mathrm{C}_{0}$ : initial concentration of phosphate or $\operatorname{arsenic}(\mu \mathrm{g} / \mathrm{L})$ and $\mathrm{t}=$ residence time in the column (h); $d$ : water flow rate in the column $(\mathrm{mL} / \mathrm{min})$.

The efficiency of removal $R(\%)$ was evaluated using the relation (3):

$\mathrm{R}(\%)=\frac{q_{\text {tot }}}{m_{\text {tot }}} \times 100$

\section{Results}

\section{Physico-chemical characteristics of water}

Table 2 presents the values of water characteristics. Data in Table 2 indicate that water sample contained a large amount of arsenic, 15 times the admissible limit value in drinking water [25]. Consequently, this water was polluted by arsenic and its consumption could cause enormous health problems. In addition, we noted the presence of anions such as phosphates, bicarbonates, chlorides and nitrates which can reduce the efficiency of arsenic removal through a competitive adsorption [2628]. High concentration of total solids shows that treatment of this water requires a pretreatment step such as filtration process in which laterite acts as a filter to remove suspended solids. That requires the use of column experiments. 
Table 2. physical-chemical composition of water sample

\begin{tabular}{|c|c|c|c|c|c|c|c|c|}
\hline Parameter & $\mathbf{T}\left({ }^{\circ} \mathbf{C}\right)$ & $\mathbf{p H}$ & $\mathbf{E C}$ & Turbidity & $\mathbf{T S S}$ & $\mathbf{T H}$ & $\mathbf{T A}$ & $\mathbf{D S}$ \\
$(\boldsymbol{\mu S} / \mathbf{c m})$ & $(\mathbf{N T U})$ & $(\mathbf{m g} / \mathbf{L})$ & $\left({ }^{\circ} \mathbf{F}\right)$ & $(\mathbf{m g} / \mathbf{L})$ & $(\mathbf{m g} / \mathbf{L})$ \\
\hline Value & 26.30 & 7.23 & 495 & 0 & 21 & 7.97 & 11.32 & 237 \\
\hline Limit value & 25 & $6.5-8$ & 300 & $\leq 5$ & 26 & $7-15$ & $*$ & $*$ \\
\hline
\end{tabular}

\begin{tabular}{|c|c|c|c|c|c|c|c|c|c|}
\hline Parameter & $\begin{array}{c}\text { Total As } \\
(\boldsymbol{\mu g} / \mathbf{L})\end{array}$ & $\begin{array}{c}\mathrm{HCO}_{3}^{-} \\
(\mathbf{m g} / \mathbf{L})\end{array}$ & $\begin{array}{c}\mathrm{NO}_{3}^{-} \\
(\mathbf{m g} / \mathbf{L})\end{array}$ & $\begin{array}{c}\mathbf{F}^{-} \\
(\mathbf{m g} / \mathbf{L})\end{array}$ & $\begin{array}{c}\mathbf{C l}^{-} \\
(\mathbf{m g} / \mathbf{L})\end{array}$ & $\begin{array}{c}\mathbf{P O}_{4}{ }^{--} \\
(\mathbf{m g} / \mathbf{L})\end{array}$ & $\begin{array}{c}\mathbf{S O}_{4}{ }^{2-} \\
(\mathbf{m g} / \mathbf{L})\end{array}$ & $\begin{array}{c}\mathbf{C a}^{2+} \\
(\mathbf{m g} / \mathbf{L})\end{array}$ & $\begin{array}{c}\mathbf{M g}^{2+} \\
(\mathbf{m g} / \mathbf{L})\end{array}$ \\
\hline Value & 151 & 6.5 & 6.3 & $<\mathrm{LD}$ & 109 & 1.25 & $<\mathrm{LD}$ & 14.03 & 11.57 \\
\hline Limit value & 10 & $*$ & 50 & 1.5 & 50 & $*$ & $*$ & 200 & 50 \\
\hline
\end{tabular}

LD: Limit of detection

(*): Limit value not found

\section{Influence of physico-chemical parameters}

Effect of water flow rate

By varying the flow rate, obtained results showed a decrease in the effectiveness of the arsenic treatment from $100 \%$ to $81.15 \%$ when the flow rate varied between 6.5 to $37.5 \mathrm{~mL} / \mathrm{min}$ (Figure 3). Better treatment (100\%) was obtained when the flow rate was ranged between 6.5 and $8.5 \mathrm{~mL} / \mathrm{min}$. An increase in flow rate beyond $34.5 \mathrm{~mL} / \mathrm{min}$ to produce a lot of drinking water, caused a decrease in the arsenic removal yield up to $79 \%$. In order to produce more drinking water in short time, flow rate of $8.5 \mathrm{~mL} / \mathrm{min}$ was selected for following experiments.

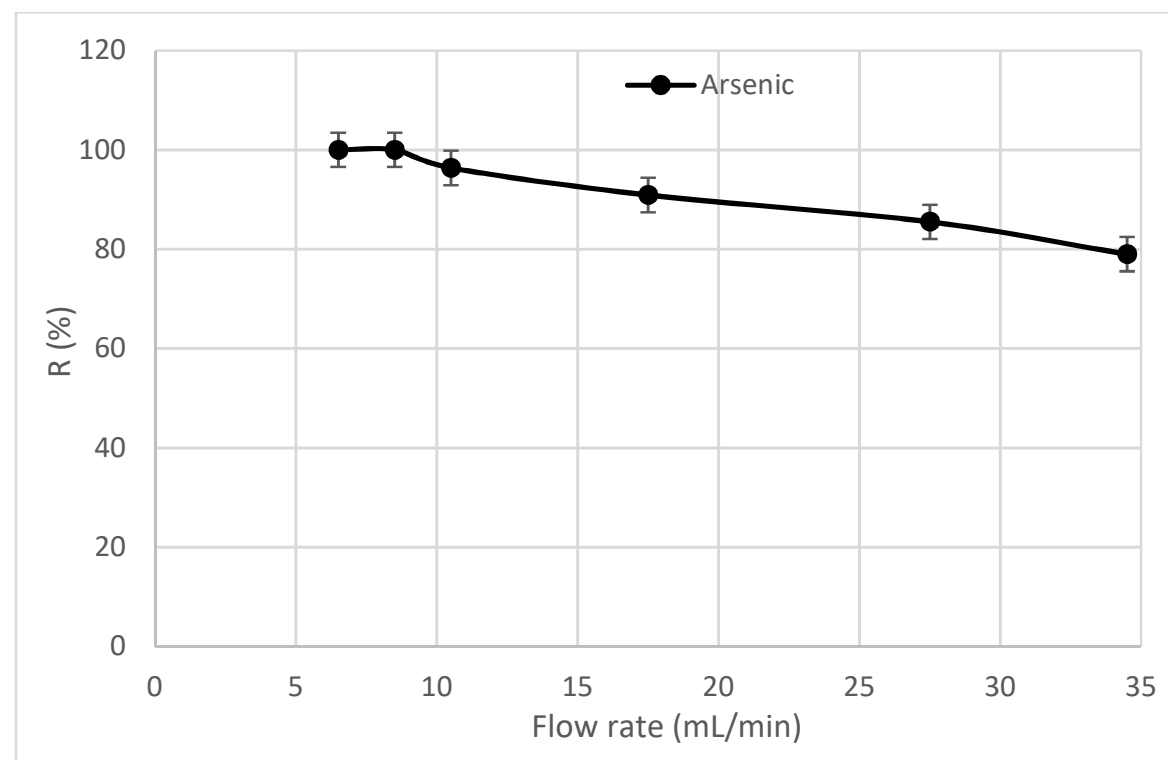

Figure 3. Effect of flow rate on arsenic removal using calcined laterite with $\mathrm{m}=40 \mathrm{~g}, \mathrm{pH}=7.04,[\mathrm{As}]_{0}=151 \mu \mathrm{g} / \mathrm{L}$, $\left[\mathrm{PO}_{4}{ }^{3-}\right]_{0}=1.25 \mathrm{mg} / \mathrm{L}$ and $\mathrm{T}=25 \pm 3^{\circ} \mathrm{C}$. 


\section{Effect of initial $\mathrm{pH}$}

The $\mathrm{pH}$ is an important parameter which strongly affects the adsorption of metal ions. It doesn't only changes the surface properties of the adsorbent, but it also affects the speciation of arsenic and phosphates in solution [29]. In the $\mathrm{pH}$ range of natural waters $(5.5 \leq \mathrm{pH} \leq 8)$, As (V) exists in $\mathrm{H}_{2} \mathrm{AsO}_{4}{ }^{-}$and $\mathrm{HAsO}_{4}{ }^{2-}$ forms while As (III) is neutral $\left(\mathrm{H}_{3} \mathrm{AsO}_{3}\right)$. For phosphates, $\mathrm{H}_{2} \mathrm{PO}_{4}{ }^{-}$ and $\mathrm{HPO}_{4}{ }^{2-}$ ions coexist in appreciable quantities. Between $\mathrm{pH} 8$ and $14, \mathrm{AsO}_{4}{ }^{3-}$ form is predominant for As (V) while those of As (III) are $\mathrm{HAO}_{3}{ }^{-}$and $\mathrm{AsO}_{3}{ }^{2-}$. Between $\mathrm{pH} 3$ and 5.5, $\mathrm{H}_{2} \mathrm{AsO}_{4}{ }^{-}$and $\mathrm{H}_{3} \mathrm{AsO}_{3}$ forms are predominant for As (V) and As (III), respectively [29] and $\mathrm{H}_{2} \mathrm{PO}_{4}{ }^{-}$ for phosphates [30]. Obtained results from $\mathrm{pH}$ change showed that the efficiency of arsenic and phosphates removal decreased when the $\mathrm{pH}$ increased (Fig. 4). Indeed, the maximum efficiency $(100 \%$ for arsenic and $85 \%$ for phosphates) was observed between $\mathrm{pH} 3$ and 5 . Between $\mathrm{pH} 6$ and 8.5, the yield of arsenic removal decreased from 97 to $78 \%$ and the one of phosphates from 76 to $72 \%$ (Fig. 4). The negatively charged species of As (V) are easily adsorbed by the electrostatic attraction force while the adsorption of As (III) is fairly independent with the $\mathrm{pH}$ change in the solution between $\mathrm{pH} 3$ and 9. For a $\mathrm{pH}$ above 8.5, there was noted a rapid decrease in adsorption which goes from 78 to $60 \%$ for arsenic and from 72 to $46 \%$ for phosphates (Fig. 4). The phosphate adsorption decreased with increasing $\mathrm{pH}$ between 3.5 and 11.02. At a given reaction time, the adsorption capacity decreased with $\mathrm{pH}$ increasing (Fig.4)

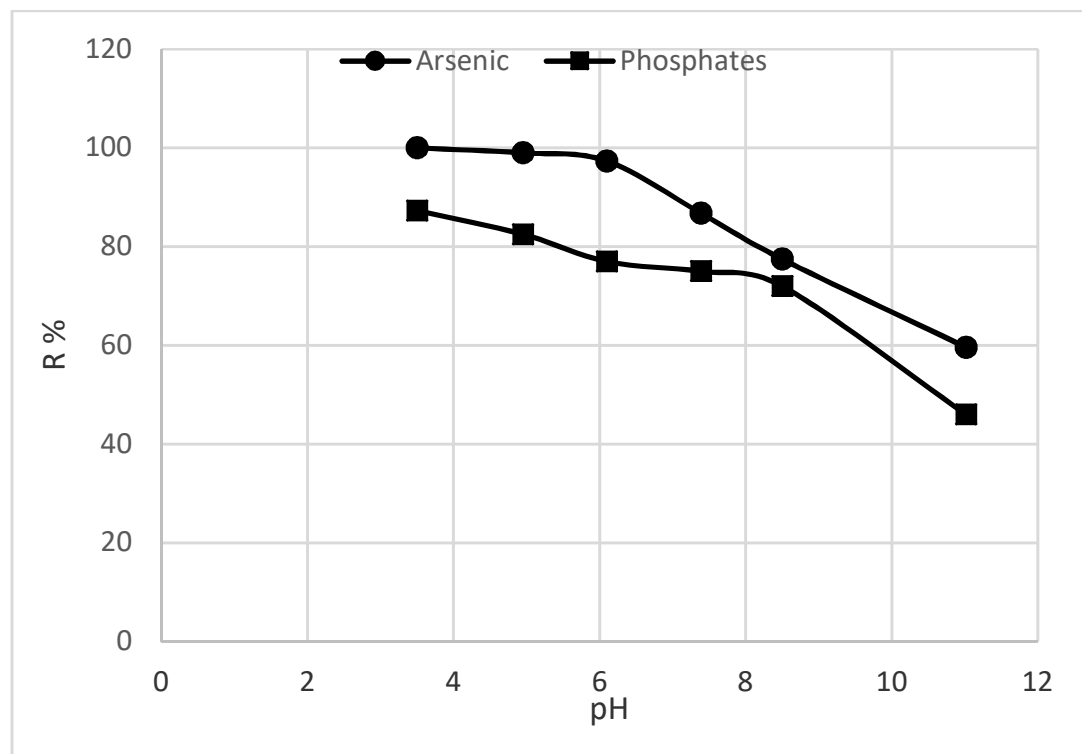

Figure 4. Effect of $\mathrm{pH}$ on the removal of arsenic and phosphate using calcined laterite with $\mathrm{m}=40 \mathrm{~g}, \mathrm{~d}=8.5 \mathrm{~mL} / \mathrm{min}$, $[\text { As }]_{0}=151 \mu \mathrm{g} / \mathrm{L},\left[\mathrm{PO}_{4}{ }^{3-}\right]_{0}=1.25 \mathrm{mg} / \mathrm{L}$ and $\mathrm{T}=25 \pm 3^{\circ} \mathrm{C}$. 


\section{Effect of initial arsenic concentration}

Changes in initial concentration of arsenic showed a decrease in arsenic adsorption from 96 to $87 \%$, corresponding to an increase in adsorption capacity from 4 to $24 \mu \mathrm{g} / \mathrm{g}$ (Fig. 5). The yield of phosphate removal increased from phosphates, chlorides and sulfates [24].

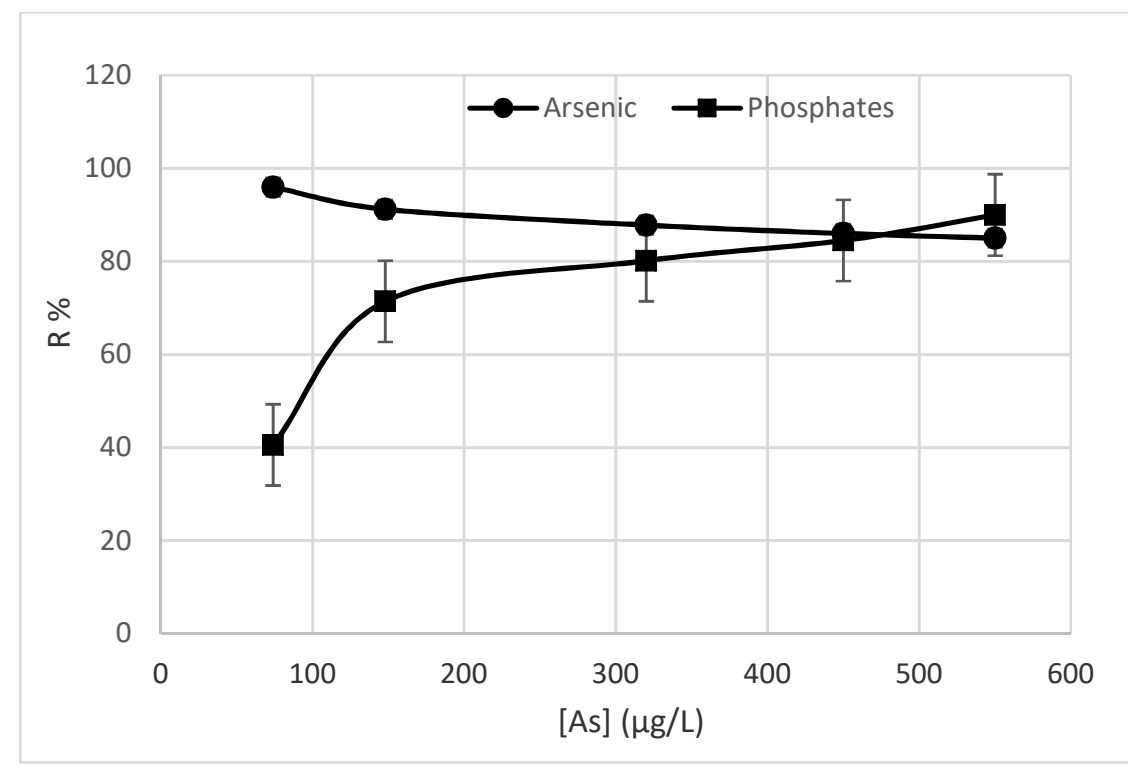

Figure 5. Effect of initial arsenic concentration on the removal of arsenic and phosphate using calcined laterite with $\mathrm{m}=40 \mathrm{~g}, \mathrm{~d}=8.5 \mathrm{~mL} / \mathrm{min},\left[\mathrm{PO}_{4}{ }^{3-}\right]_{0}=1.25 \mathrm{mg} / \mathrm{L}$ and $\mathrm{T}=25 \pm 3^{\circ} \mathrm{C}$.

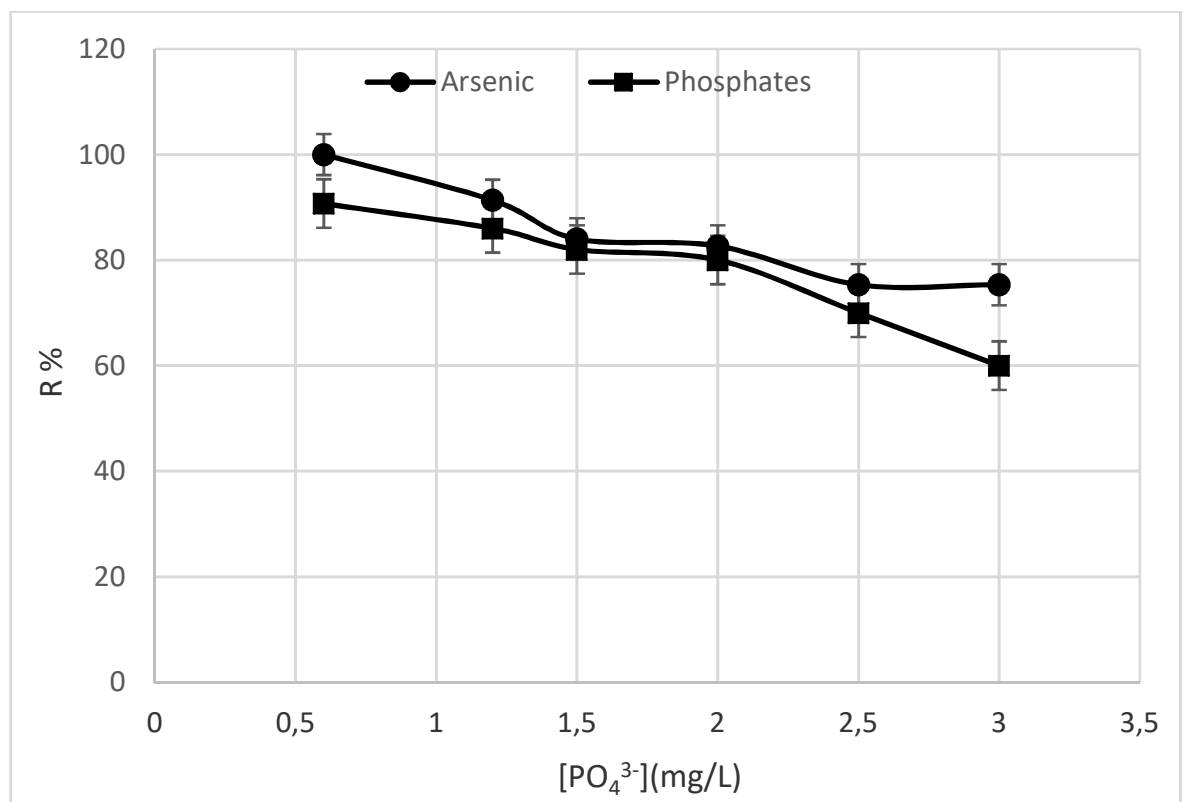

Figure 6. Effect of initial phosphate concentration on arsenic removal using calcined laterite with $\mathrm{m}=40 \mathrm{~g}, \mathrm{pH}=7.02$, $\mathrm{d}=8.5 \mathrm{~mL} / \mathrm{min},[\mathrm{As}]_{0}=151 \mu \mathrm{g} / \mathrm{L}$ and $\mathrm{T}=25 \pm 3{ }^{\circ} \mathrm{C}$. 


\section{Effect of initial phosphate concentration}

When the initial phosphate concentration increased, the yield in arsenic removal decreased from 100 to $75.33 \%$ (See figure 6).

\section{Effect of laterite quantity on breakthrough curves}

The breakthrough curves show the start of breakthrough at different bed depths between 10 and $30 \mathrm{~cm}$ (Figure 7). The breakthrough time corresponds to the moment when the arsenic concentration of treated water reached the maximum admissible value $(10 \mu \mathrm{g} / \mathrm{L})$, this is the end of the breakthrough. On the breakthrough curves, it corresponds to $\mathrm{C}_{t} / \mathrm{C}_{0}=0.06$ (Figure 7). The important data of the breakthrough curves are given in table 3 .

Table 3. Important parameters of breakthrough curves

\begin{tabular}{|c|c|c|c|c|c|}
\hline $\begin{array}{c}\text { Bed depth } \\
\mathbf{( c m})\end{array}$ & $\begin{array}{c}\text { Breakthrough } \\
\text { start (h) }\end{array}$ & $\begin{array}{c}\text { Breakthrough } \\
\text { end (h) }\end{array}$ & $\begin{array}{c}\text { Treated Water } \\
\text { volume (L) }\end{array}$ & $\begin{array}{c}\text { Adsorption } \\
\text { capacity }(\boldsymbol{\mu g} / \mathbf{g})\end{array}$ & $\begin{array}{c}\text { Treatment } \\
\text { efficiency } \\
\mathbf{( \% )}\end{array}$ \\
\hline $\mathbf{1 0}$ & 0.75 & 4 & 2.04 & 7.4 & 57.72 \\
\hline $\mathbf{2 0}$ & 2.75 & 11 & 5.61 & 10.3 & 59.24 \\
\hline $\mathbf{3 0}$ & 4.2 & 18 & 9.18 & 11.7 & 59.55 \\
\hline
\end{tabular}

Data in Table 3 show that more the bed depth is higher, more the breakthrough time is longer and the volume of water treated is greater. Indeed, when the bed depth increased from $10 \mathrm{~cm}$ to $30 \mathrm{~cm}$, the start of breakthrough increased from 0.75 hour to 4.2 hours while the end of breakthrough went from 4 hours to 18 hours. This corresponds to a breakthrough duration of $3.25 \mathrm{~h}$, $8.25 \mathrm{~h}$ and $13.8 \mathrm{~h}$ for bed depths of $10 \mathrm{~cm}, 20 \mathrm{~cm}$ and $30 \mathrm{~cm}$, respectively. This increase in laterite mass inside of the column from $40 \mathrm{~g}$ to $120 \mathrm{~g}$ caused an increase in the adsorption capacity which went from 7.4 to $11.7 \mu \mathrm{g} / \mathrm{g}$ while the treatment yield varied slowly from $57.72 \%$ to $59.54 \%$. However, the non-similar form of breakthrough curves with different masses of laterite could be explained by a heterogeneous distribution of the laterite grains / particles in the column. 


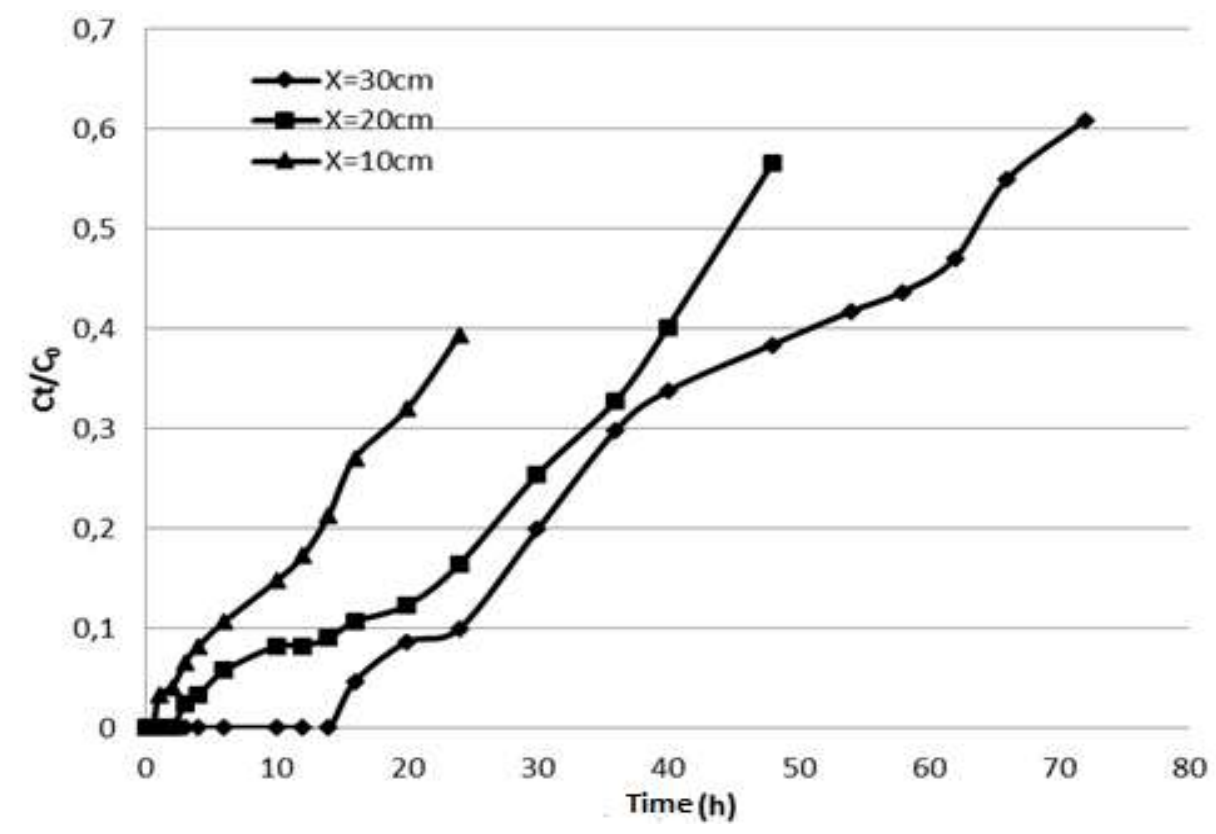

Figure 7. Effect of laterite weight on breakthrough curves using $[\mathrm{As}]_{0}=151 \mu \mathrm{g} / \mathrm{L}, \mathrm{pH}=7.02$ and $\mathrm{T}=25 \pm 3{ }^{\circ} \mathrm{C}$.

Competition mechanism between arsenic and phosphate

The initial reaction between soil particles and phosphate is adsorption on variable charge surfaces. The initial adsorption reaction is followed by a solid state diffusion of the adsorbed phosphate ions down an electrochemical gradient into the adsorbing particles [30].

Many authors have studied the treatment of arsenic by competitive adsorption with phosphates and other anions in water $[27,28]$. In the present study, the maximum adsorption of arsenates in the presence of phosphate occurred at a $\mathrm{pH}$ between 3.5 and 6 in which $\mathrm{pH}$ range is expected to coexist the inner spheres complexes and the outer spheres complexes. In the competitive system, the peaks of the outer sphere are barely separated from the relatively stronger species of the inner sphere. Consequently, the inner sphere complexes are favored in the presence of phosphate and a small amount of these surface complexes, possibly including the complex of iron arsenates formed with ferric ions on the surface of laterite, co-adsorbed with phosphate without competing for the same surface site. Lindegren and Persson [12] showed the formation of iron (III) oxalates which coadsorb with phosphate without competing for the same active site on goethite. As (V) adsorbs competitively with phosphate on the adsorbent surface and the binding affinity constant of $\mathrm{AsO}_{4}{ }^{3-}$ would be seven times that of $\mathrm{PO}_{4}{ }^{3-}[8]$. At high $\mathrm{pH}$, the reacting surfaces are negatively charged and increasing cation concentration increases adsorption of phosphate. That is the opposite at low $\mathrm{pH}$ where the reacting surfaces are positively charged [30]. Obviously, there is no effect at the $\mathrm{pH}$ of zero point charge whose the value decreases as the amount of adsorption increases [31] and it is also decreased by prior reaction with phosphate [32]. 


\section{Desorption of arsenic}

Results of desorption study indicated a decrease in the amount of desorbed arsenic when the volume of $\mathrm{NaOH}$ solution passed through the column increased (Figure 8). Indeed, calculations revealed that $1,300 \mathrm{~mL}$ of $\mathrm{NaOH}$ solution could desorb $86.8 \%$ of arsenic. The desorption capacity of laterite in the present study is greater than that of laterite used in arsenic removal experiments in Vietnam [33].

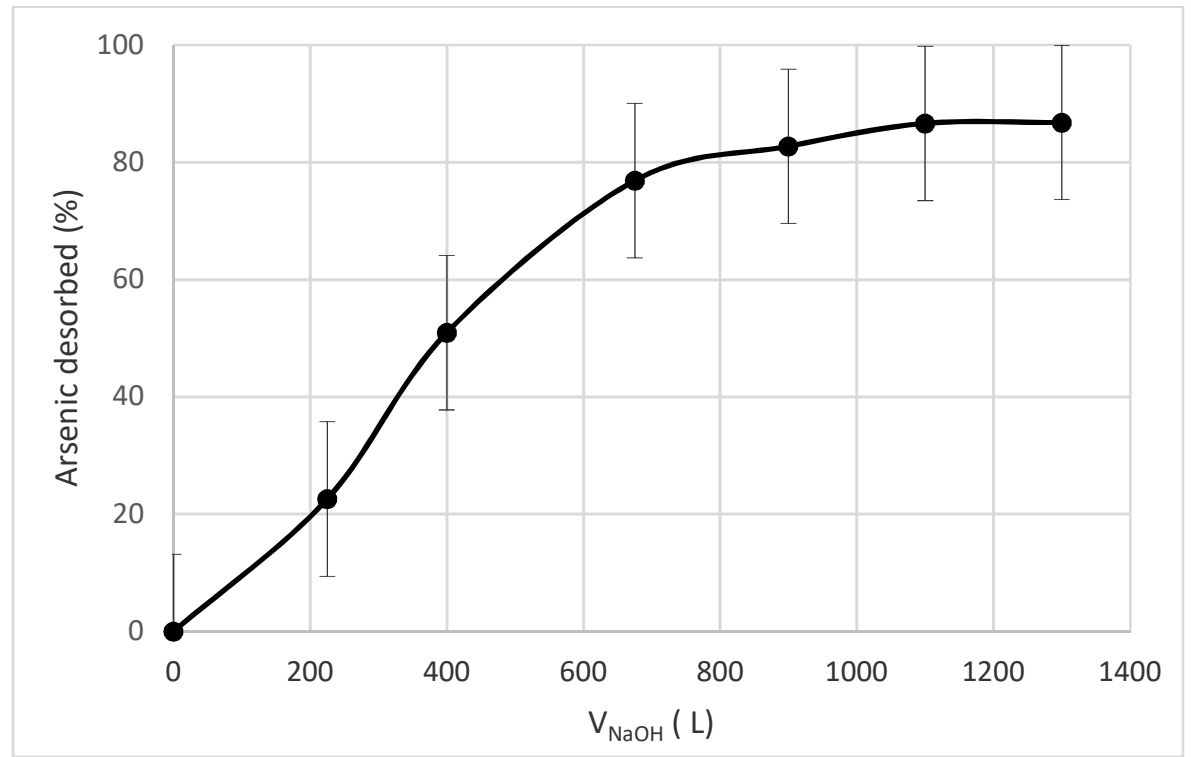

Figure 8. Arsenic desorption using $\mathrm{NaOH}$ solution onto $40 \mathrm{~g}$ of laterite with $\mathrm{d}=8.5 \mathrm{~mL} / \mathrm{min}$, $[\mathrm{As}]_{0}=1.692 \mathrm{mg} / \mathrm{L}$ and $\mathrm{T}=25 \pm 3^{\circ} \mathrm{C}$.

\section{Re-adsorption on regenerated laterite}

Many studies have been focused on the regeneration of laterite but few of them concerned re-adsorption on the regenerated material $[1,16,33,34]$. In this work, results of arsenic re-adsorption showed that at all times, the residual concentration of arsenic with regenerated laterite was lower than the one obtained using calcined laterite (Figure 9). The breakthrough time of the adsorbent material decreased from 4 hours to 12 hours using calcined laterite and regenerated laterite respectively, indicating better performance of regenerated laterite in the arsenic adsorption process. 


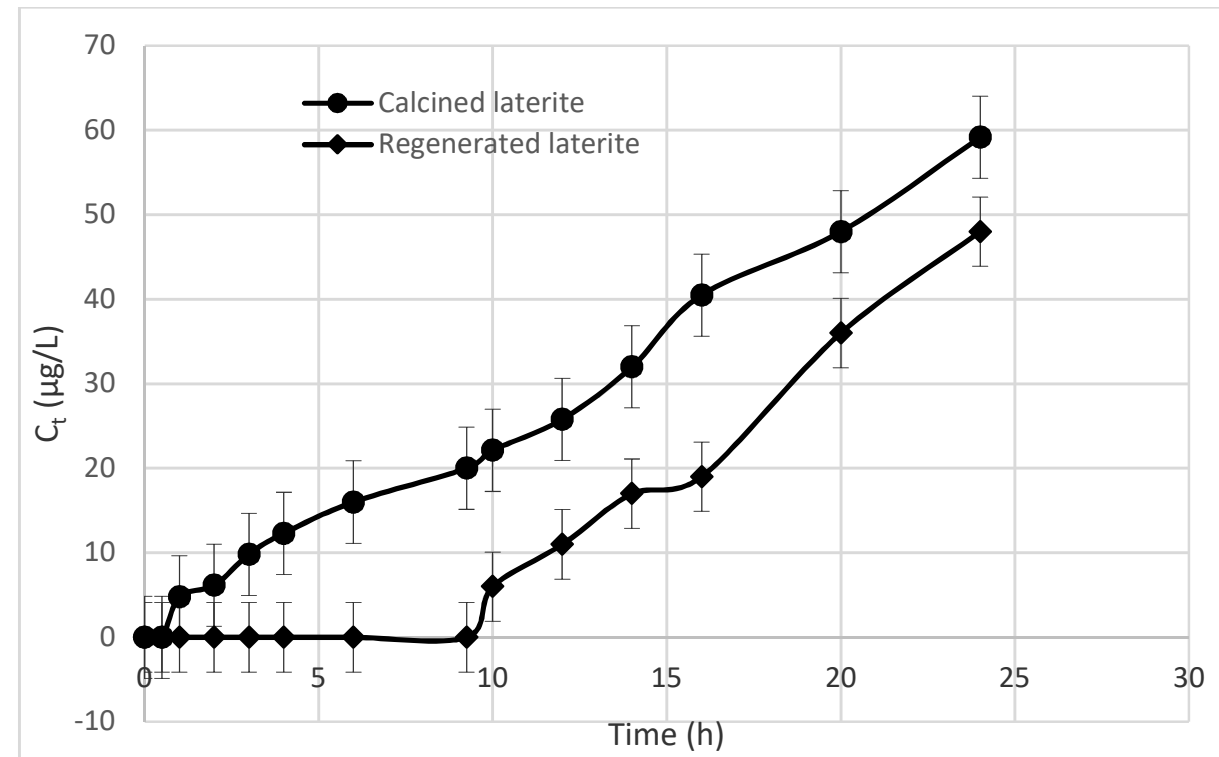

Figure 9. Arsenic adsorption and re-adsorption curves using regenerated and calcined laterites with using $\mathrm{m}=40 \mathrm{~g}$, $\mathrm{d}=8.5 \mathrm{~mL} / \mathrm{min}, \mathrm{pH}=7.23,[\mathrm{As}]_{0}=151 \mu \mathrm{g} / \mathrm{L}$ and $\mathrm{T}=25 \pm 3^{\circ} \mathrm{C}$.

the one of calcined laterite and the difference is

In order to confirm the efficiency of more noticeable after 4 hours (Figure 10). regenerated laterite in arsenic removal, the Indeed, the adsorption capacity of regenerated adsorption capacities of both two laterites were laterite increased from 0.9 to $29.3 \mu \mathrm{g} / \mathrm{g}$ while that calculated at all times during 24 hours of of calcined laterite varied between 0.9 and 26 treatment. Results indicated that the adsorption $\mu \mathrm{g} / \mathrm{g}$ under the same experimental conditions. capacity of regenerated laterite was greater than

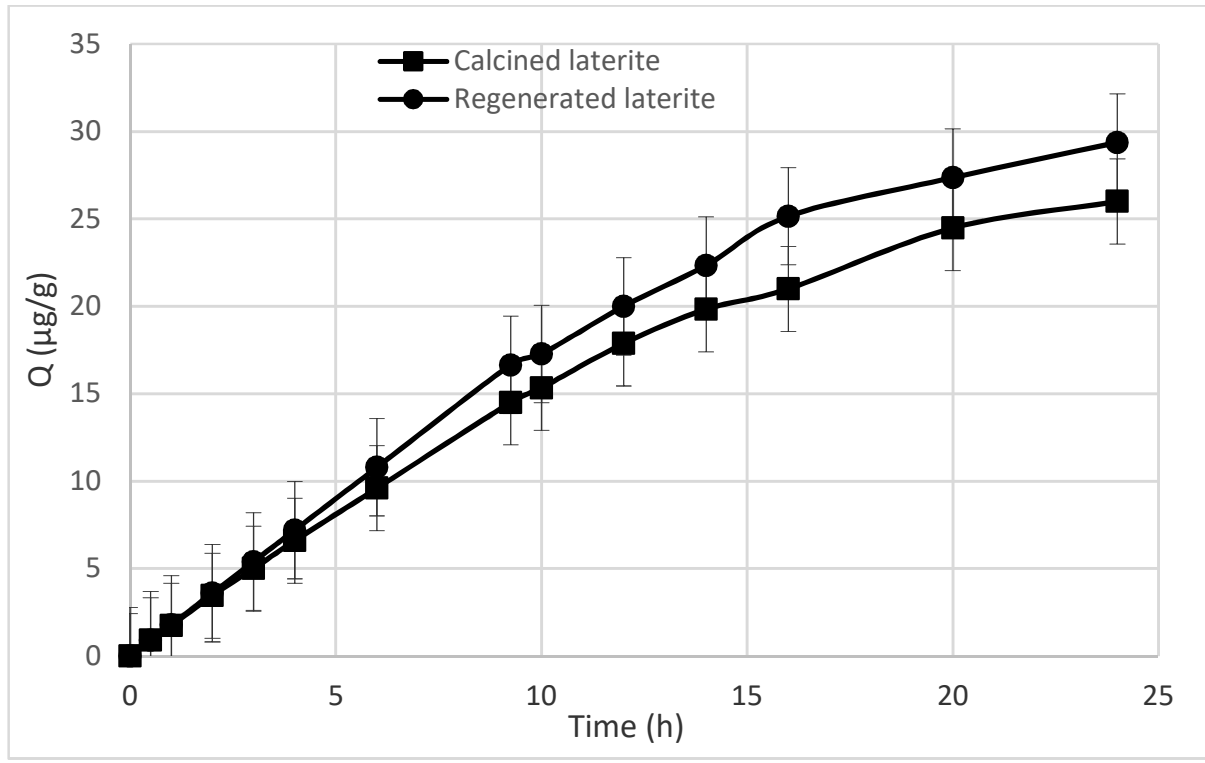

Figure 10. Comparison of adsorption capacity between calcined laterite and regenerated laterite using $\mathrm{m}=40 \mathrm{~g}$, $\mathrm{d}=8.5 \mathrm{~mL} / \mathrm{min},[\mathrm{As}]_{0}=151 \mu \mathrm{g} / \mathrm{L}, \mathrm{pH}=7.23$ and $\mathrm{T}=25 \pm 3^{\circ} \mathrm{C}$. 


\section{Discussion}

The decrease in treatment efficiency with flow rate increase could be explained by a reduction in the residence time of arsenic ions for their adsorption into the pores of laterite [1]. The efficiency of the treatment at low values of flow rate is in agreement with literature data which indicate the moving, the migration and the fixation of arsenates and arsenites on the adsorbent surface $[21,35]$.

Maximum removal of arsenic in at acid $\mathrm{pH}$ would be due to the attraction forces between the main species $\left(\mathrm{H}_{2} \mathrm{AsO}_{4}^{-}, \mathrm{H}_{3} \mathrm{AsO}_{3}\right.$ and $\left.\mathrm{H}_{2} \mathrm{PO}_{4}^{-}\right)$and the positive charge on the surface of laterite because $\mathrm{pH}$ is less than $\mathrm{pH}$ at zero point charge which is $5.74[7,36]$. The quick decrease in adsorption of arsenic after $\mathrm{pH} 6$ was due to the electrostatic repulsion between the negatively charged surface of laterite and the negatively charged As (V) ions [37]. The decrease of phosphate adsorption with $\mathrm{pH}$ increasing was reported in literature using the goethite as adsorbent $[38,39]$. Literature revealed that the increase of $\mathrm{pH}$ is unfavorable for the adsorption of arsenic and phosphates on calcined laterite compared to raw laterites $[17,36]$. According to Barrow [40], desorption of phosphates on soils increases when $\mathrm{pH}$ increases. The decrease of phosphates adsorption with increasing values of $\mathrm{pH}$ could be explained by competition of phosphates and hydroxyls ions on material surface which became more negative. The completion became less and less favorable for phosphates and arsenic on the material sites with the $\mathrm{pH}$ increasing. The effects of increasing $\mathrm{pH}$ can be seen as a balance between increasing proportion of divalent ions and increasingly unfavourable electric potential [30].

The increase in adsorption capacity with initial concentration could be due to occupation of the active sites and their gradual saturation [41]. The improvement in adsorption of phosphate would be favored by the reduction of the repulsion forces between phosphate and negative surface of laterite following the fixation of arsenic, and the competition with arsenates.

The decrease in the arsenic adsorption when initial phosphates concentration increased would be due to competition between phosphates and arsenates for the occupation of active laterite sites [42]. However, the slower decrease in arsenic removal compared to predicating data could be explained by the occupation of active sites which decrease when $\mathrm{PO}_{4}{ }^{3-}$ anions are approached comparatively to arsenates by repulsion effect due of their small sizes [4]. Other authors reported that in the competitive adsorption between phosphate and arsenic on iron oxides, there are specific sites and common sites on the surface of the adsorbent for phosphates and arsenates [17]. Similar results in previous study shows that sorption of arsenate by soils decreased when phosphate concentration in solution increased and sorption of phosphate decreased when arsenate concentration increased [43]. 
The increase of adsorption capacity for arsenic with laterite weight could be due the increase of the surface area of laterite and active sites on the surface. This result is in agreement with works of Nguyen [17] indicating that the efficiency of treatment in the column would depend on the bed depth, the flow rate and the temperature.

The decrease of arsenic amount during the arsenic desorption when the soda volume increased could be explained by a break in the electrostatic bonds formed during the arsenic adsorption and the better selectivity of the adsorbent for arsenic. The presence of hydroxyl ions increased the negative charge on the surface of calcined laterite promoting the release of arsenic comparatively to phosphate. This high percentage of arsenic desorption was due to a strong presence of As (V) compared to As (III) and that the oxidized arsenic was linked by weaker forces on the surface of calcined laterite compared to reduced arsenic. In addition, the future increase in the concentration of the alkaline solution would increase the percentage of arsenic desorption but simultaneously dissolves the iron oxides on the surface of laterite [24].

High adsorption capacity of regenerated laterite would be due to treatment with $\mathrm{NaOH}$ solution during the desorption of arsenic which contributed to increase the value of the isoelectric $\mathrm{pH}$ of regenerated laterite which modifies the surface charge of the material and this releases the phosphates to favor the adsorption of arsenates and arsenites onto released sites. This result is in agreement with a previous study which revealed that the efficiency of regenerated material would be due to the fact that the surface of adsorbent material becomes more active and more porous after treatment with $\mathrm{NaOH}$ [44].

The improvement of the adsorption capacity of regenerated laterite would be favored by a decrease in the zeta potential which was high in calcined laterite because of the significant electronegativity of oxygen atoms in iron oxides, aluminum oxide and silicon. Sanjoy et al. [34] indicated that adsorbing arsenic on soils is a userfriendly technique because the adsorbent is regenerable, reusable and more effective in a new treatment.

\section{Conclusions}

This work was able to assess the performance of calcined laterite for the removal of arsenic and phosphates from water. Water used contained an appreciable quantity of arsenic, higher than the admissible value. Column experiments revealed the influence of flow rate, initial $\mathrm{pH}$, adsorbent weight, initial concentration of arsenic and phosphate as well as a competitive effect between arsenates and phosphate. The removal of arsenic and phosphate decreased when $\mathrm{pH}$ increased while an increase in flow rate caused a decrease in the efficiency of adsorption process. Indeed, the maximum arsenic removal was $100 \%$ while $85 \%$ of phosphate when $\mathrm{pH}$ ranged between 3.5 and 6 with a flow rate of 8.5 $\mathrm{mL} / \mathrm{min}$. The variation of initial arsenic 
concentration caused an increase of adsorption capacity which was influenced by phosphates, and more the phosphate concentration is higher, adsorption capacity of calcined laterite become lower. The regenerated material indicated a greater efficiency in removing arsenic with a breakthrough time which increased from $4 \mathrm{~h}$ for calcined laterite to $12 \mathrm{~h}$ for regenerated laterite. At this regards, calcined laterite would be used as adsorbent of the future experiments but its adsorptive potential could be improved by chemical treatments.

\section{Acknowledgements}

Authors would like to thank the University Joseph KI-ZERBO and the AINA laboratory of water analysis. We would like to thank to $\mathrm{Mr}$. Adama SAWADOGO for his technical support in carrying out this work.

\section{References}

[1] Sanou Y. Traitement des eaux avec des charbons actifs, GFH et latérite. Editions Universitaires Européennes, tvisrasco, (2019): 26p.

[2] National Research Council NRC. Arsenic in drinking water. National Academy Press, Washington, DC, ISBN 0-309-06333-7, (1999): 330 p. https://doi.org/10.17226/6444.

[3] Borano T., Boonchai W., Chatpet Y. Adsorptive behavior of low-cost modified natural clay adsorbents for arsenate removal from water. Inter. J. Goemate. 2017, 12 (33) : 2531 1-7.

[4] Juan Francisco R. Z. Développement d'un procédé d'élimination de l'arsenic en milieu aqueux, associant électro catalyse et filtration. Thèse unique, Université de Grenoble, France, 2012, 127p.

[5] Bretzler A., Lalanne F., Nikiema J., Podgorski J., Pfenninger N., Berg M., Schirmer M. Groundwater arsenic contamination in Burkina Faso, West Africa: Predicting and verifying regions at risk. Sci. Total Environ. 2017, 584(585) : 958-970.

[6] Ahalem B. Etude expérimentale et modélisation de l'élimination des cations métalliques de l'acide phosphorique issu du procédé humide : Application aux cas de l'aluminium, le fer et le cuivre. Thèse Unique, Université de Constantine, Algérie, 2005, 96p.

[7] Sandotin L. C. Abattement des phosphates des eaux usées par adsorption sur des géomatériaux constitués de Latérite, grès et schistes ardoisiers. Thèse unique en Cotutelle, Université de Lorraine (France) et Université Nangui Abrogoua (Côte d'Ivoire), 2014, 118-175.

[8] Jeong Y., Maohong F., Leeuwen J.V., Belczyk J.F. Effect of competing solutes on arsenic (V) adsorption using iron and aluminum oxides. J. Environ. Sci. 2007, 19: 910-919.

[9] H. Klapper Control of Eutrophication in Inland Water. Ellis Horwood limited: Chichester, West Sussex, England, 1991, 337p.

[10] Zhou Q., Gibson C. E., Zhu Y. Evaluation of Phosphorus Bioavailability in Sediments of Three Contrasting Lakes in China and the UK. Chemosphere. 2001, 42: 221-5. Doi: 10.1016/S0045-6535(00)00129-6.

[11] Sparks D. L. Environmental Soil Chemistry. Elsevier Science, $2^{\text {nd }}$ Ed. Elsevier-Academic Press, New York, 2003, 1-352.

[12] Lindegren M., Persson P. Competitive adsorption between phosphate and carboxylic acids: quantitative effects and molecular mechanisms. Eur. J. Soil Sci. 2009, 60: 982-993. Doi: 10.1111/j.13652389.2009.01171.x

[13] K. R. Henken, A. Hutchison (2009). Arsenic chemistry in Arsenic Environmental Chemistry, Health Threats and Waste Treatment. Edition John Wiley \& Sons, Chichester, pp. 9-68.

[14] Youcef L., Ouakouak A., Boulanouar D., Achour S. Etude du pouvoir adsorbant du charbon actif en poudre pour l'élimination des phosphates des eaux naturelles. Larhyss J. 2014, 17 :35-46. 
[15] Guy B. Phosphore, azote et prolifération des végétaux aquatiques. Courrier de l'environnement de l'INRA. 2003, n48 (511)- 74203 : 13-26.

[16] Maiti A., Gupta S. D., Basu J. K., De S. Adsorption of arsenite using natural laterite as adsorbent. Department of Chemical Engineering, Indian Institute of Technology, Kharagpur. 2007, 721302: 350-360.

[17] Nguyen T. H. N. Using Laterite Materials to Remove Phosphate in Water. Inter. J. Eng. Res. Technol. 2017, 6 (07): 561-567.

[18] Giorgis I., Bonetto S., Guistetto R., Lawane A., Pantet A., Rossetti P., Thomassin J-H., Vinai R. The lateritic profile of Balkouin, Burkina Faso: Geochemistry, mineralogy and genesis. J. African. Earth. Sci. 2014, 90: 31-48.

[19] Sanou Y., Balougoun C. K., Tiendrebeogo R., Kabore R., Tchakala I., Pare S. Physico-chemical and spectroscopic properties of two laterite soils for applications in arsenic water treatment. Inter. J. Multidiscip. Res. Dev. 2020, 7 (5): 12-17.

[20] Sanou Y., Pare S. Arsenic pollution through drinking groundwater in Burkina Faso: Research of a cheap removal technology. In: Water perspectives in emerging countries: linking water security to sustainable development goals, M. Nolasco, E. Carissimi, E. UrquietaGonzalez (Eds.), Cuvillier Verlag Göttingen, Germany, 2018, 137-148.

[21] Sanou Y., Pare S., Phuong T. T. Nguyen, Phuoc V. Nguyen Experimental and Kinetic modeling of As (V) adsorption on Granular Ferric Hydroxide and Laterite. J. Environ. Treat. Tech. 2016, 4 (3) : 62-70.

[22] De Jong S. J., Kikietta A. Une particularité bien localisée, heureusement présence d'arsenic en concentration toxique dans un village près de Mogtédo (Haute-Volta). Bulletin de Liaison du Comité Interafricain d'Etudes Hydrauliques. 1981, 44p.

[23] Rice E. W., Baird R. B., Eaton A. D., Clesceri L. S. Standard methods for the examination of water and wastewater. American Public Health Association APHA,
AWWA, WEF. 22 ${ }^{\text {th }}$ Edition, Washington DC, 2012, 20013710 .

[24] World Health Organization, WHO. Guidelines for Drinking Water Quality. $4^{\text {th }}$ Edition, WHO Press, Geneva, Switzerland, 2011, 569p.

[25] Driehaus W., Jekel M., Hildebrandt U. Granular ferric hydroxide: a new adsorbent for the removal of arsenic from natural water. J. Water Supply: Res. Technol. Aqua. 1998, 47: 30-35.

[26] Gupta A., Sankaramakrishnan N. Column studies on the evaluation of novel spacer granules for the removal of arsenite and arsenate from contaminated water. Biores. Technol.2010, 101(7): 2173 - 2179.

[27] Malher J., Persson I. Rapid adsorption of arsenic form aqueous solutions by ferrihydrite-coated sand and Granular Ferric Hydroxide. Appl. Geochem. 2013, 37 : $179-189$.

[28] Ouvrard S. Couplage matériau / procédé d'adsorption pour l'élimination sélective d'arsenic présent en traces dans les eaux. Thèse de doctorat unique, Institut National Polytechnique de Lorraine, France, 2001, 1-222.

[29] Guo X., Chen F. Removal of arsenic by bead cellulose loaded with iron oxyhydroxide from groundwater. Environ. Sci. Technol. 2005, 39 : 6808-6818.

[30] Lenoble V. Elimination de l'Arsenic pour la production d'eau potable: oxydation chimique et adsorption sur des substrats solides innovants. Thèse unique, Université de Limoges, France, 2003, 165p.

[31] Maiti A., Basu J. K., De S. Experimental and kinetic modeling of $\mathrm{As}(\mathrm{V})$ and $\mathrm{As}(\mathrm{III})$ adsorption on treated laterite using synthetic and contaminated groundwater: Effects of phosphate, silicate and carbonate ions. Chem. Eng. J. 2012, $191: 1-12$.

[32] Luengo C., Brigante M., Antelo J., Avena M. Kinetics of phosphate adsorption on goethite: Comparing batch adsorption and ATR-IR measurements. J. Colloid Inter. Sci. 2006, 300: 511-518.

[33] Strauss R., Brummer G. W., Barrow N. J. Effects of crystallinity of goethite: II. Rates of sorption and 
desorption of phosphate. Eur. J. Soil Sci. 1997, 48: 101-

144.

[34] Sanou Y., Phuong T. T. Nguyen, Pare S., Phuoc V. Nguyen (2019). The removal of As (V) from aqueous solutions using Ferromagnetic Activated Carbon: equilibrium and kinetic studies. Rev. Sci. Eau., 32(2), 179192. DOI: $10.7202 / 1065206$ ar.

[35] Basu T., Nandi D., Sen P., Ghosh U. C. Equilibrium modeling of $\mathrm{As}(\mathrm{III}, \mathrm{V})$ sorption in the absence/presence of some groundwater occurring ions by iron(III)-cerium(IV) oxide nanoparticle agglomerates: A mechanistic approach of surface interaction. Chem. Eng. J. 2013, 228: 665-678.

[36] Luengo C., Brigante M., Avena M. Adsorption kinetics of phosphate and arsenate on goethite: a comparative study. J. Colloid Inter. Sci. 2007, 311 (2): 354-360.

[37] Phuong T. T. Nguyen, Sanou Y., Pare S., Ha M. B. Removal of arsenic from groundwater using Lamdong laterite as a natural adsorbent. Pol. J. Environ. Stud. 2020, 29(2): 1305-1314. DOI: https://doi.org/10.15244/pjoes/103028.

[38] Sanjoy K. M., Anjali P., Tarasankar P. Arsenic removal from real-life groundwater by adsorption on laterite soil. J. Hazard. Mater. 2008, 151, 811-820.

[39] Suresh M. K., Jeykumar R. K. C. Preparation of amino-modified iron oxide, nano adsorbent and calcined laterite for chromium (VI) and copper (II) removal. Inter. J. Biotech Trends Technol. 2018, 8 (2): 18-20. 